\title{
The Use of Metadiscourse by Saudi and British Authors: A Focus on Applied Linguistics Discipline
}

\author{
Thamer Binmahboob ${ }^{1}$ \\ ${ }^{1}$ King Abdulaziz Military Academy, Saudi Arabia \\ Correspondence: Thamer Binmahboob, King Abdulaziz Military Academy, Saudi Arabia.
}

Received: December 17, 2021

Accepted: January 26, 2022

Online Published: January 30, 2022

doi: $10.5539 /$ elt.v15n2p78

URL: https://doi.org/10.5539/elt.v15n2p78

\begin{abstract}
This study investigated the use of metadiscourse tools by Saudi and British authors in Applied Linguistics discipline. In particular, the study tried to identify the kinds of metadiscourse markers used by Saudi and English authors in ALRAs and to determine the most and least frequent metadiscourse makers. In order to achieve these goals, (10) ALRAs written by Saudi authors and (10) ALRAs written by British authors served as the corpus of the study. The research articles were selected from well-known journals and published between $2010-2018$. Hyland's (2005) model was used to find out the distribution of metadiscourse markers in each type of corpora. The findings showed interactive metadiscourse markers are used more than the interactional metadiscourse markers. Compared with the British authors, the Saudi authors were found to use metadiscourse markers more than the British authors. The Saudi authors employed all metadiscourse sub-categories more frequently than the British authors except frame markers, evidentials, endophoric markers, and self-mentions. In addition, it was found that transitions were the highly frequent metadiscourse markers in the whole corpora, followed by hedges, evidentials, boosters, and attitude markers, respectively. On the other hand, engagement markers were the least frequent metadiscourse markers in the whole corpora.
\end{abstract}

Keywords: metadiscourse, research articles, applied linguistics, Hyland's (2005) Model, markers

\section{Introduction}

Metadiscourse is an essential and significant means of facilitating communication and interaction as well as supporting the writer's viewpoint and setting up a connection with the audience (Williams, 1981). It makes the writer build the text in an appropriate manner through a logical connection of the presented ideas.

It is an original component of academic writing. It is one of the ways that enables writers to convey their ideas, viewpoints and opinions with the public in order to create a certain impression upon the audience. In addition, it is a kind of discourse that featuring factors which are used to distinguish between the ideas and to help the readers to follow the flow of ideas in the text (Hyland, 2002). Metadiscourse is essential in academic writing. On the other hand, its tools are used to fulfill objectivity which enhances the honesty of the author (Hyland, 2005). It is considered as an art while using or avoiding metadiscourse since the inappropriate use of metadiscourse might violate the written paper.

Various studies, such as Valcro-Grace, 1996; Buton, 1999; Maurenan, 1993; Swales, 1990; Hyland, 2000, were conducted to find out the significance of metadiscourse. Its resources are employed to grant a way to grasp the interpersonal resources to explore something special to a certain disciplinary community (Hyland \& Tse, 2004). It means that metadiscourse is applied by the writers to allow them express their attitudes towards the audience and organize their texts.

Metadiscourse was studied in the domain of contrastive rhetoric and implies the notion that writing and language are culturally placed (Connor, 1996). In order to verify this notion, different studies were conducted. The focus was on the metadiscourse resources in the different languages, societies and culture. However, according to El-Seidi 2000, most of the studies used English as universal point of reference. Also, the comparison of metadiscourse use in English and Arabic languages is understudies. Few numbers of researchers such as Abbas (2011) reported that there are statistically significant differences in the use of metadiscourse markers between Arabic and English research articles. Moreover, Elheky \& Elbahlal (2012) reported that the Arabic authors tend to use hedging devices than the native authors due to their uncertainty of their propositions. 
Based on the literature, metadiscourse denotes interpretations and allow writers to express their attitudes to the actuality of the statements they accompany, thereby giving unproven claims warily and indecisive assertions. Yet, very little is known about the function of metadiscourse and how it is expressed in different languages, especially in Arabic. A considerable amount of research has been conducted on texts such as medicine, engineering texts, biology, but still a less-focused research effort is made on Arabic contexts. Since no much evidence can be found in literature, this study has shed light on the frequency of metadiscourse in texts written by Saudi writers and British writers in the field of applied linguistics.

\subsection{Statement of the Problem}

The metadiscourse use in the research articles written by British and Saudi writers in the field of applied linguistics is under-researched. There is a scarcity in the contrastive studies (English and Arabic) utilizing the metadiscourse approach. Much work has been made in different contexts on the use of metadiscourse markers such as Iran, China, and Malaysia. Also, other studies focused on metadiscourse features in research articles, textbooks and Ph.D. dissertations, and in different disciplines other than applied linguistics. Elheky \& Elbahlal (2012) reported that the Arabic writers do not highly conform to the standard norms of academic metadiscourse and lack many essentials of the academic writing. So, the current study attempts to explore the differences in the use of metadiscourse in a number of applied linguistics-based research articles written by Saudi and British authors.

\subsection{Questions of the Study}

The current study attempts to answer the following questions:

1) What are the kinds of metadiscourse markers used by Saudi and English authors in applied linguistics research articles?

2) What are the most and least frequent metadiscourse makers used by Saudi and English authors in applied linguistics research articles?

3) What are the similarities and differences in the use of metadiscourse markers between the Saudi and English authors in applied linguistics research articles?

\subsection{Objectives of the Study}

The following objectives attempt to be achieved by the current study:

1) To identify the kinds of metadiscourse markers used by Saudi and English authors in applied linguistics research articles.

2) To determine the most and least frequent metadiscourse makers used by Saudi and English authors in applied linguistics research articles.

3) To explore the similarities and differences in the use of metadiscourse markers between the Saudi and English authors in applied linguistics research articles.

\subsection{Significance of the Study}

The importance of the study stressed the exploration of the metadiscourse features used by Saudi and British authors and in giving insights about the proper norms of academic writing. This study is highly important from the pedagogical perspective since it would have a role in curriculum design, error analysis, and use of effective teaching techniques of metadiscourse. Moreover, the appropriate standards of academic writing will be explored, especially for those who work in the field of applied linguistics. On the other hand, this study would allow the writers to enhance their sub-skills and assess their drawbacks. Finally, the current study is significant for the researchers in the field of applied linguistics.

\section{Literature Review}

Metadiscourse denotes interpretations and enable writers to illustrate their attitudes to the actuality of the statements they accompany, thereby giving unproven claims warily and indecisive assertions and to find out the audiences' needs. In fact, one of the linguistic devices that the writers use in order to organize their texts, attract the readers, and to show their attitudes towards the topic and the audience is metadiscourse. Hyland (2000: 109) defines metadiscourse as "a linguistic resource utilized by the author to show his or her proposition to the readers". Metadiscourse is employed as an umbrella to comprise a set of cohesive and interpersonal features that link the written material with the broader context. According to Hyland (1998), metadiscourse is used by the writer to make the readers interpret and understand the material in the manner preferred by the writer in line with the values of a certain discourse community. Some authors have restricted metadiscourse to the qualities of 
textual organization (e.g. Valero-Graces, 1996), but, universally, metadiscourse is viewed as the linguistic and rhetorical representation in the written material in order to organize the content and to reflect the expressive implications of what is written (Schiffrin, 1980).

According to Hyland (2000), metadiscourse is the tool that enables the writer to transform the difficult material into an easily understood prose by the reader and into a coherent text connected with the broader context. In addition, metadiscourse tools give the writers the chance to convey their ideas, personality, credibility, and attitudes towards the audiences.

Wishnoff (2000) argued that metadiscourse tools are used to motivate the readers and guarantee their acceptance. Metadiscourse can be shown in different forms to offer different alternatives to the readers to have their own interpretations and everyone can have his or her own interpretation. In fact, this is a kind of politeness strategy which is taken towards the readers in order to soften the face-threatening activity.

The theorists of metadiscourse appear to have different perspectives of the concept, foundations, and limits of metadiscourse. This contributed in providing different models of discourse. Metadiscourse can be realized in different ways (Hyland, 2005). So, different classifications of metadiscourse were presented such as the classification of Vande Kopple (1985), the classification of Crismore et al. (1993), the classification of Hyland (1998), and the classification of Hyland \&Tse (2004).

For example, Vande Kopple's (1985) model of metadiscourse consisted of seven categories as follows:

1) Text connectives (e.g. first, next, however, as we shall see in the coming part)

2) Code glosses (in other words, to explain the meaning of .....)

3) Illocution markers (e.g. I hypothesize that, to sum up, we argue that)

4) Validity markers (e.g. perhaps, may, undoubtedly)

5) Narrators (e.g. John announced that .....)

6) Attitude markers (e.g. I find it is interesting that)

7) Commentary (e.g. you may need to read the first edition first)

A model of discourse was suggested by Crismore et al. (1993) was based on their modification of Vande Kopple's (1985) model of metadiscourse. Two essential categories were retained, interpersonal and textual, but they rearranged the subcategories.

Hyland (2005) presented a model which involves two kinds of metadiscourse: the interactive and interactional metadiscourse. The interactive metadiscourse involves the features that are employed in order to organize the content in the manner that the target readers like to realize in a convincing and coherent way. This is also referred to as textual metadiscourse resources (Ali, 2016, p. 40). The interactional metadiscourse involves that features that engage the audience and present changes for them to take part in the discourse by acknowledging them of the author's attitudes towards the content and the audience themselves.

Several studies have investigated the use of metadiscourse in academic writing, especially in English and non-English corpus. Kawase (2015) discussed metadiscourse tools in two important genres; they are $\mathrm{PhD}$ dissertations and articles. The researcher discussed how metadiscourse is used in the introduction sections of both $\mathrm{PhD}$ dissertations and articles. The findings revealed that many authors make a larger employment of metadiscourse in their introduction parts. The prominent changes include a larger utilization of phrases pointing out to past research, fewer indications to other sections of the text, and minimal utilization of phrases referring to researcher's presence. It was also shown that such differences come from the genre-specific characteristics, involving that authors of introduction parts in doctoral dissertations submit previews of the next sections.

Mojica (2005) concluded that Filipino writers use modals and probabilities in their English papers. Hyland (2005), found that EFL authors use unqualified writing and that stronger modals are used as a way of showing commitment. In (2009), two hedging expressions in data available in British English were studied by Gries and David. They found that hedges are as per the genres. Hyland (2002) analyzed the use of directives and hedges in textbooks, published papers and second language student's essays. He concluded that directives are used for different purposes across different branches of Knowledge.

Moreover, metadiscourse tools in research articles written by native English authors in English language teachers were examined by Salek (2014). Salek reported that the abstract and conclusion parts have higher percentage of metadiscourse tools compared with other sections in the articles. 
Metadiscourse in both Arabic and Saudi research is understudied. However, a limited number of studies can be traced. For instance, Al Bahlal (2015) discussed the hedging devices used in business and scientific texts written by Saudi Students. The use of hedging was compared in business texts as a scientific genre and social texts. Using QB text analyser software, the frequency and realization of hedges in 40 scholarly articles were analyzed. The study shows that more hedges are used in the social texts. He concluded that hedging is used to qualify writers' commitment, and express probability rather than certainty. It is also widely used in academic writing because it saves the writers' face. In academic writing, hedging is a significant device used in order to convince readers and avoid their refusal of their arguments. The writers' ability, especially in social texts, to hedge is an indication of their success in presenting their propositions.

Metadiscourse in Arabic and English research articles were compared by Alotaibi (2015). Forty four English and Arabic abstracts written by Arabic writers were examined. The researcher used Hyland's (2005) model. It was demonstrated that there is an excessive use of interactive markers in the abstracts in the two languages. Furthermore, it was found that the Arabic abstracts use transition markers more than the English abstracts. English abstracts were found to use frame markers more than the Arabic ones.

In his study, Tabrizi (2011) examined changes in the attitudes of females and males after reading a scientific and humanistic text. The study revealed that there are noticeable variations between the two genres. Females achieved high scores than men because they show acceptance of others' different views and emphasizing with other people. In addition, Mazahri (2001) claims that women use metadiscourse more than men to avoid being wrong in their judgment.

Alharbi \& Swales (2011) investigated the employment of metadiscourse in both English and Arabic abstracts made by Arab students. The focus was on the promotional features, pronoun use, and move structure. The findings showed that move structure is not used extensively. Also, the results showed that the two kinds of abstracts did not involve much self-mentions.

Sultan (2011) made a study on Arabic research articles. He made a comparison between the discussion parts in Arabic and English papers in the domain of Linguistics. The papers were written by Arabic writers and native writers. The researcher found that the Arabic writers applied metadiscourse markers higher than their English counterparts. In particular, the Arabic writers used transitions and code glosses more than any other tool of metadiscourse. However, the English native writers were found to use frame and endophoric markers.

Regarding the Arabic-English contrastive researches, the employment of two metadiscourse marker were examined by El-Seidi (2000); the validity markers and attitude markers in Arabic and English writing. The use of these two types of metadiscourse was investigated in the argumentative writing through argumentative essays written by Arabic native speakers and English native speakers. There were differences in the use of the two kinds of metadiscourse markers in terms of frequency and the preferred norms, but the two categories of metadiscourse seem to involve themselves into the text and this refers to the commitment the text and the writers' attitudes towards the text (El-Seidi, 2000). Also, Abbas (2011) compared the interactive and interactional metadiscourse in both English and Arabic research articles. The research corpus consisted of seventy discussion sections. The results of the study showed that metadiscourse plays a big role in research articles in both Arabic and English language. However, the results showed that the Arabic writers tend to use metadiscourse markers more than the English writers.

Based on the literature, metadiscourse is a key component of academic writing. However, variations in the use of metadiscourse markers exist among language, disciplines, and genres. There were attempts by the researchers to identify the patterns and frequency of metadiscourse markers used by the writers from different culture. Yet, very little is known about the function of metadiscourse and how it is expressed in different genres. Many studies has been made on scientific materials such as medicine, biology, engineering texts, but still a less-focused research effort is made on Arabic authors. According to the nature of Arabic rhetoric, there is an expectation that metadiscourse is used more frequently than with English writers. Since no much evidence can be found in literature, the current study attempts to compare the use of metadiscourse markers between Arabic and English writers. Moreover, contrary to previous research, this research focuses on the metadiscourse markers used by both Arabic and English writers in the field of Applied Linguistics.

\section{Methodology}

\subsection{Research Design}

The descriptive approach is adopted with its quantitative dimension. The descriptive approach is that approach that leans on the study of the phenomenon as it exists in reality and is concerned with the accurate description 
and a statement of characteristics. This approach gives a numerical description through figures and tables showing the size of the phenomenon or size or degree of association with other phenomena.

The descriptive approach links, interprets, categorizes the data and determines the quality of the relationship of variables, causes and trends. The results are drawn investigated. The main objective of the descriptive approach is to make relationships and put these relationships for analysis. Also, it provides a picture of the extent of change in previous phenomena through which the researcher can study the future. The quantitative research uses numbers in the analysis of data and processes the results statistically.

In this research, the researcher used the quantitative approach only. Quantitatively, the research presents the frequency and percentage of the occurrence of each metadiscourse marker in each of the Saudi and British research articles.

\subsection{Corpus}

The corpus of this research consists of (20) research articles in applied linguistics. The (20) research articles were divided as follows: (10) research articles for Saudi researchers and (10) research articles for British researchers. The analysis focused on two parts in each research article: the abstract and the introduction. A list of the selected research articles can found in appendix (A).

The research articles were selected on the basis that they are of the same length approximately. The research articles were downloaded from the well-known, refereed, and recently published applied linguistics journals and from the websites of Saudi digital libraries. The British research articles were taken from many journals such as Oxford Journal, EAP Journals, and ESP Journals. The research articles written by Saudi authors were taken from a number of journals such as Arab World English Journal, International Journal of English Linguistics, English Language Journal, and Journal of Emerging Trends in Educational Research and Policy Studies.

The research articles that represented as the corpus of the study included research articles written within the field of applied linguistics during 2010 to 2018 in English language and written by Saudi and English authors. All the research articles were retrieved electronically from a number of elite and influential applied linguistics journals.

So as to examine different writings, then balancing out the issue of idiosyncrasy and particularity of the researchers' styles, the research articles were randomly selected and with an attention not to include the same researchers more than once. The articles whose writers were British and Saudi were selected for the analysis. When an article has multiple authorship, all authors must be native British authors for English research articles and native Saudi researchers for the Saudi research articles. The use of native researcher in each type of British and Saudi journal articles was a minimum criterion to ensure the use of the British and Saudi writing style.

A further important concern was to involve a variety of subjects that would cancel the problem of a single topic affecting the generalizability of the findings. This was made in order to make the corpus as much representative as possible. However, it has to be considered that the findings have to be carefully interpreted and generalized because of the research limitations.

\subsection{Instrumentation}

Since the study aims to identify the metadiscourse markers used by the Saudi and British researcher in the field of applied linguistic, this study used the model of Hyland (2005) that categorized metadiscourse markers into two main categories: interactive metadiscourse and interactional metadiscourse. This model is particularly selected since it suits the purpose of the study as it shifts from the prior treatments of metadiscourse towards a model that can capture the underlying principles of academic writing. Table 1 shows Hyland's (2005) model that was used as the data collection instrument in the present research:

Table 1. Analysis Model: Hyland's (2005) Model

\begin{tabular}{cl}
\hline Interactive Metadiscourse & \\
\hline 1. & Transitions \\
2. & Frame markers \\
3. & Endophoric \\
markers & \\
4. & Evidentials \\
5. & Code glosses
\end{tabular}




\section{Interactional Metadiscourse}

1.

2.

3.

4.

5.

markers
Hedges

Boosters

Attitude markers

Self-mentions

Engagement

The validity and reliability of the research instruments were verified by the researcher. Validity means that the instrument is suitable for the purpose for which it was designed. The researcher achieved the face validity of the model by submitting it to a number of experts and requesting their opinions on the suitability of the model to the research objectives. The model is considered valid since it was used in many similar studies and adopted from the original study of Hyland (2005).

Reliability is the extent to which the research instruments give the same result on repeated trials. In order to evaluate the reliability of the data coding, 3 research articles were separately coded by the researcher and a second rater who was an MA student specializing in applied linguistics. The second rater was trained by the author and was given a coding scheme involving definitions/explanations, examples, and detailed instructions. There was a high agreement between the two coders in classifying the metadiscourse markers.

\subsection{Procedures \& Analysis}

The researcher applied the following procedures to collect data for the research and to analyze the collected data:

1) (10) Journal articles were collected by the researcher for each of the British and Saudi researchers in the field of applied linguistics. The articles were tabulated and classified as Saudi and British articles.

2) The PDF files of the researcher articles were converted into text file in order to allow further analysis and the count of metadiscourse markers.

3) Metadiscourse markers were searched electronically in the whole British and Saudi corpus using Wordsmith Tools (Version 5.0). After the determination of metadiscourse markers in each corpus, each metadiscourse marker was analyzed in context to assure that it acted as a metadiscourse feature.

4) In the two types of corpus, the search for metadiscourse categories was executed electronically and then examined manually in context.

5) After retrieving the research articles from the journals and selecting the ones which constitute the corpus of the research, the items considered to be metadiscourse were determined and taxonomized in the texts based on Hyland's (2005) model of metadiscourse, however, data analysis was not confined to predetermined search items; other possible realizations frequently occurring in the analyzed text were also taken into consideration. Due to the great contextual nature of metadiscourse and the notion that one form can act as either a propositional or metadiscoursal function, a context-sensitive analysis of each metadiscourse feature was executed.

6) Since the quantity of data in each language may not the same due to length, the number of metadiscourse elements was computed per 1000 words to allow comparison across corpora of unequal sizes.

7) The overall Frequency of metadiscourse resources in RAs was calculated.

8) In data analysis, the journal site, outline of the article, the writers' names, acknowledgments, literature review, findings, discussion, conclusion, recommendations, and reference lists were removed. The analysis focused on the abstract and introduction only.

9) After the findings are presented, the researcher discussed these finding and linked them to the literature and previous studies on metadiscourse.

\section{Results \& Discussion}

The results are taken from (10) applied linguistics research articles written by British authors and (10) applied linguistics research articles written by Saudi authors. To carry out the analysis, the abstract and introductions sections were cut from the research articles. Using Hyland's (2005) model of metadiscourse markers, the results showed the number of metadiscourse markers used by Saudi authors is (870) markers and the number of metadiscourse markers used by British authors is (668) markers. 
Table 2. Metadiscourse Markers Use by Saudi and British Authors

\begin{tabular}{lllll}
\hline \multirow{2}{*}{ Category } & \multicolumn{2}{c}{ Saudi Authors } & \multicolumn{2}{l}{ British Authors } \\
\cline { 2 - 5 } & Frequency & $\mathbf{\%}$ & Frequency & \% \\
\cline { 4 - 5 } Interactive Metadiscourse & & & & \\
\hline Transitions & 312 & $35.86 \%$ & 274 & $41 \%$ \\
Frame markers & 23 & $2.64 \%$ & 30 & $4.49 \%$ \\
Endophoric markers & 10 & $1.15 \%$ & 19 & $2.84 \%$ \\
Evidentials & 49 & $5.63 \%$ & 61 & $9.13 \%$ \\
Code glosses & 37 & $4.25 \%$ & 32 & $4.79 \%$ \\
Interactional Metadiscourse & & & & \\
Hedges & 204 & $23.44 \%$ & 132 & $19.7 \%$ \\
Boosters & 54 & $6.2 \%$ & 39 & $5.83 \%$ \\
Attitude markers & 48 & $5.51 \%$ & 37 & $5.53 \%$ \\
Self-mentions & 32 & $3.67 \%$ & 41 & $6.1 \%$ \\
Engagement markers & 11 & $1.26 \%$ & 3 & $0.45 \%$ \\
Total & $\mathbf{8 7 0}$ & & $\mathbf{6 6 8}$ & \\
\hline
\end{tabular}

Table 2 shows that the research articles written by Saudi authors use a higher number of interactive and interactional metadiscourse markers than the research articles written by British authors (Saudi, $n=870$; British, $\mathrm{n}=668$ ). Looking into the subcategories of each of interactive metadiscourse and interactional metadiscourse, a number of linguistic differences emerge.

Generally, the findings show that transitions are the highest frequent category of metadiscourse in the two types of texts, followed by hedges, evidentials, boosters, attitude markers, self-mentions, code-glosses, frame markers, endophoric markers, and engagement markers, respectively.

\section{A. Interactive Metadiscourse}

Interactive metadiscourse markers comprise five sub-categories of metadiscourse markers: transitions, frame markers, endophoric markers, evidentials, and code glosses. The below figure shows the percentage of each interactive metadiscourse marker in the texts written by each of the Saudi and British authors. The below figure shows the distribution of interactive metadiscourse markers:

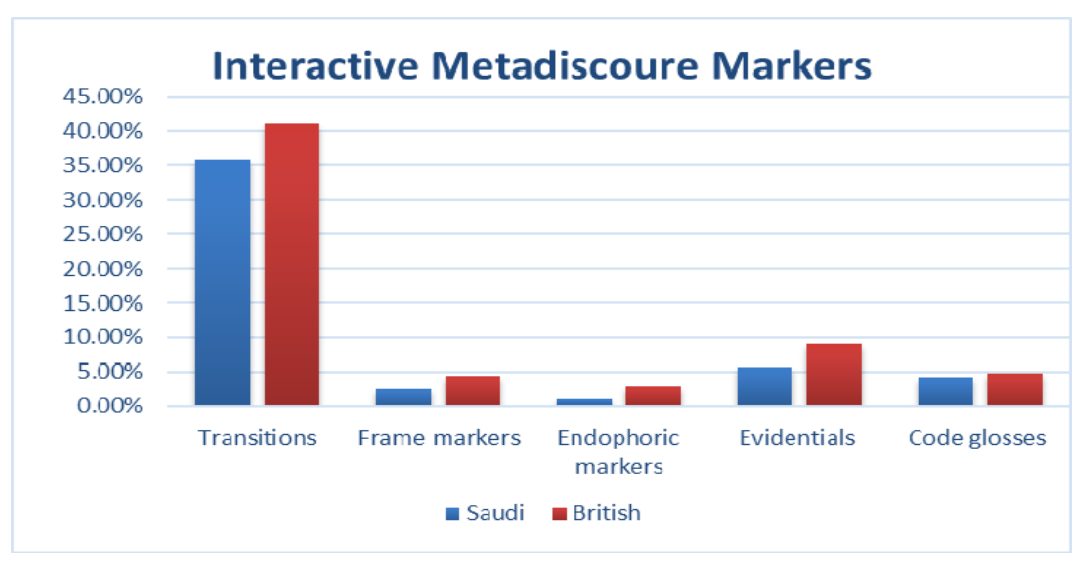

Figure 1. Interactive Metadiscourse Markers

It is shown that interactive metadiscourse markers are the most frequent markers in the two types of texts. In particular, transitions were the most frequent sub-category, followed by evidentials, code glosses, frame markers, and endophoric markers, respectively. Below is a description of each sub-category:

a) Transitions

Transitions are the markers that imply additive, consequential, and contrastive moves in the discourse. Examples of transitions are and, but, thus, and in addition, etc. The analysis shows transitions were the most frequent items 
in the RAs written by Saudi authors (35.86\%) from a total of (870) metadiscourse items found in the RAs written by Saudi writers. Also, the analysis shows that transitions were the most frequent items in the RAs written by British authors (41\%) out of (668) metadiscourse items found in the RAs written by British writers. But, generally, the Saudi writers have used transitions more than the British writers when calculating their percentage from the number of metadiscourse markers in the whole corpus. Below are examples of the transitions used by both types of writers:

British: "In addition, moderator analyses revealed ......" (Lee et al., 2014, p. 345).

Saudi: "Conversely, showing concern for the hearer...." (Altayari, 2017, p. 37).

Saudi: "Thus, this increasing need ......" (Alhadidi, 2017, p. 64).

\section{b) Frame Markers}

Frame markers are the items that demonstrate text boundaries or the components of the text structure. Examples of frame markers are to conclude, finally, and my goal here is, etc. The analysis shows that the frame markers are used by the Saudi writers at $(2.64 \%)$ and used by the British authors at $(4.49 \%)$. This means that the British authors use frame markers more than the Saudi authors. Below are examples of the frame markers used by the two types of authors:

British: "The final product of the study ....." (Vaclav Brezina Dana Gablasova, 2015, 2015, p. 1).

Saudi: "In conclusion, the findings of this study ....." (Altayari, 2017, p. 37).

\section{c) Endophoric Markers}

Endophoric markers are the items that point to information in other sections of the text or to draw the attention to additional materials. Examples of endophoric markers are mentioned-above, see figure, and in section, etc. The analysis shows that the endophoric markers are used by the Saudi writers at $(1.15 \%)$ and used by the British authors at (2.84\%). This means that the British authors use endophoric markers more than the Saudi authors. Below are examples of the endophoric markers used by the two types of authors:

British: "The instances above capture the phenomenon as a ......" (Emeka-Nwobia, 2014, p. 2).

Saudi: "Despite of the previous argument, there seems ......" (Alhadidi, 2017, p. 66).

\section{d) Evidentials}

Evidentials are the items that point to the sources of information from other materials. Examples of evidentials are according to $X$, and $X$ (2010) mentions that, etc. The analysis shows that the evidentials are used by the Saudi writers at $(5.63 \%)$ and used by the British authors at $(9.13 \%)$. This means that the British authors use evidentials more than the Saudi authors. Below are examples of the evidentials used by the two types of authors:

British: "Faltis (1989) views that code mixing ....." (Emeka-Nwobia, 2014, p. 2).

Saudi: "This goes in line with Ackerman (2006) who ......" (Aljumah, 2012, p. 100).

\section{e) Code Glosses}

Code glosses are the items to assist the readers understand the role or task of ideational material. Examples of code glosses are in other words, such as, and namely, etc. The analysis shows that the code glosses are used by the Saudi writers at $(4.25 \%)$ and used by the British authors at $(4.79 \%)$. This means that the British authors use code glosses more than the Saudi authors. Below are examples of the code glosses used by the two types of authors:

British: "In a typical urban setting like Lagos," (Emeka-Nwobia, 2014, p. 1).

Saudi: “ words, such as making a promise" (Altayari, 2017, p. 37).

In general, the above findings show that the applied linguistics research articles use a relatively large number of interactive metadiscourse markers in the two types of corpora. This indicates the importance of interactive metadiscourse. This corresponds with Crismore et al. (1990) who reported that it is not valid to regard metadiscourse markers marginal to the discourse.

The analysis shows that the British authors and Saudi authors make use of the transitions in larger proportion ( $41 \%$ vs., $35.86 \%$, respectively). However, it was shown that the British authors use frame markers more than the Saudi ones ( $4.49 \%$ vs. $2.64 \%$, respectively. In addition, it was found that the British authors were found to use endophoric markers, evidentials, and code glosses more than the Saudi writers. This result may demonstrate that Saudi and British authors depended more on the interactive markers than on the interactional ones. This 
finding corresponds with result of Alharbi \& Swales (2011) that both the Arabic writers and English writers tend to communicate their propositions to their readers by using more interactive metadiscourse markers.

The results show that the Saudi and British writers are similar in prioritizing the subcategories of interactive metadiscourse. Saudi writers tend to depend maximally on transitions $(35.86 \%)$ and minimally on endophoric markers $(1.15 \%)$. On the other hand, the British writer tend to depend maximally on transitions $(41 \%)$ and minimally on endophoric markers (2.84\%). This means that both British and Saudi writers of applied linguistics research articles do their best to connect their propositions through their extra dependence on transitions in their writings. This result corresponds with the results of Kawase (2015) and Abbas (2011) who reported that the Arabic writers use more interactive metadiscourse markers than the English writers.

\section{B. Interactional Metadiscourse}

Interactional metadiscourse markers comprise five sub-categories of metadiscourse markers: hedges, boosters, attitude markers, self-mentions, and engagement markers. The below figure shows the distribution of interactional metadiscourse markers:

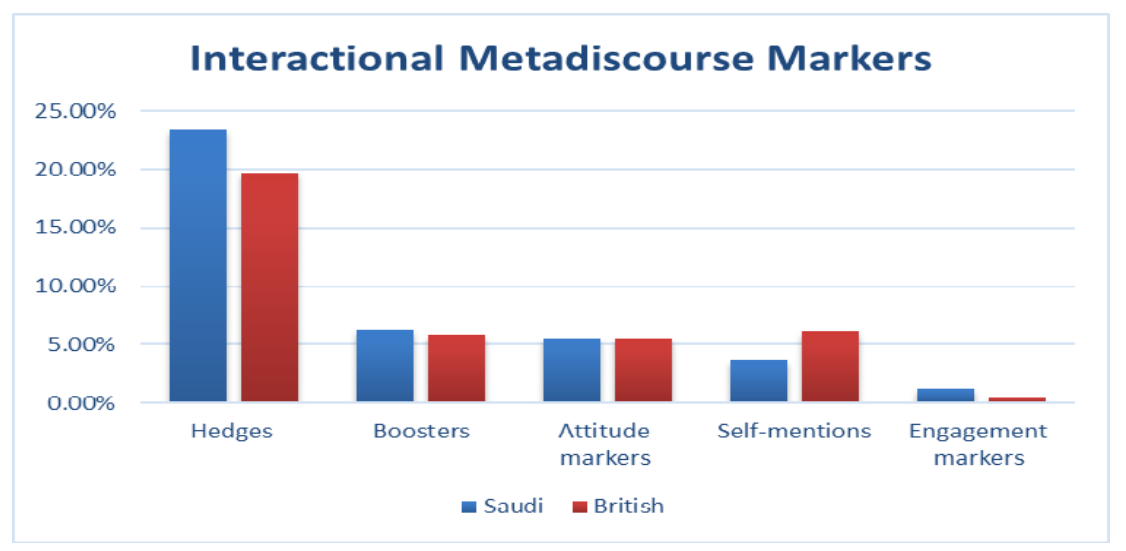

Figure 2. Interactional Metadiscourse Markers

It is shown that interactional metadiscourse markers are the least frequent markers in the two types of texts. In particular, hedges were the most frequent sub-category, followed by boosters, attitude markers, self-mentions, and engagement markers, respectively. Below is a description of each sub-category:

\section{a) Hedges}

Hedges are the devices that show the author's degree of commitment to proposition. Examples of hedges are seem, appear, might, can, about, and possibly, etc. The analysis shows that the hedges are used by the Saudi writers at $(23.44 \%)$ and used by the British authors at (19.4\%). This means that the Saudi authors use hedges more than the British authors. Below are examples of the hedges used by the two types of authors:

British: "which potentially influence group dynamics ...." (Nazari, 2014, p. 105).

Saudi: "However, it seems that teachers and students have ...." (Alhaysony, 2017, P. 70).

\section{b) Boosters}

Boosters are the metadiscourse markers used to stress the author's certainty of a certain proposition. Examples of boosters are in fact, it is clear that, and definitely, etc. The analysis shows that the boosters are used by the Saudi writers at (6.2\%) and used by the British authors at (5.83\%). This means that the Saudi authors use boosters more than the British authors. Below are examples of the boosters used by the two types of authors:

British: "Due to the fact that people are increasingly becoming bilinguals ..." (Emeka-Nwobia, 2014, p. 1).

Saudi: "In fact, Ellis argued that sufficient knowledge....." (Alhaysony, 2017, p. 70).

\section{c) Attitude Markers}

Attitude markers are the items that show the author's evaluation or attitude towards a certain issue. Examples of attitude markers are I agree, unfortunately, and surprisingly, etc. The analysis shows that the attitude markers are used by the Saudi writers at (5.51\%) and used by the British authors at (5.53\%). This means that the British authors use attitude markers more than the Saudi authors. Below are examples of the attitude markers used by the two types of authors: 
British: "It is naturally much more agreeable ......" (Nazari, 2014, p. 106).

Saudi: "Based on the researcher's experience in teaching English ...." (Sanad, 2014, p. 82).

\section{d) Self-mentions}

Self-mentions are the items that point to the writer's presence and mainly marked by the use of first person pronouns and possessive pronouns. Examples of self-mentions are your, I, we, my, you, our, and etc. The analysis shows that the self-mentions are used by the Saudi writers at (3.67\%) and used by the British authors at (6.1\%). This means that the British authors use self-mentions more than the Saudi authors. Below are examples of the self-mentions used by the two types of authors:

British: "We interpret these ....." and "Our conclusion points out areas of PI research" (Lee et al., 2014, p. $345)$.

Saudi: "With $m y$ belief that there is not a comprehensive ....." (AlShammiry, 2016, p. 128).

\section{e) Engagement Markers}

Engagement markers are the items used to setup a connection with the audience. Examples of engagement markers include note that, you can observe that, and consider, etc. The analysis shows that the engagement markers are used by the Saudi writers at $(1.26 \%)$ and used by the British authors at $(0.45 \%)$. This means that the Saudi authors use engagement markers more than the British authors. Below are examples of the engagement markers used by the two types of authors:

British: "But why are other bilinguals...?" (Jason Rothman Jeanine Treffers-Daller, 2014, p. 94).

Saudi: "One of the important perspectives that needs to be noted......" (Almegren, 2017, p. 243).

In analyzing the interactional discourse, it is found that the British authors and Saudi authors make use of the hedges in larger proportion (23.44\% vs., $19.7 \%$, respectively). Also, it was shown that the Saudi authors use hedges more than the British. In addition, it was found that Saudi authors use boosters, attitude markers, and engagement markers more than the British authors. In contrast, the British authors use self-mentions more than the Saudi authors. On the other hand, it was shown that engagement markers are the least frequent interactional metadiscourse marker in the two type of texts, with the Saudi scholar using engagement markers more than the British authors.

The difference between the two types of writers is more prominent in the use of interactive discourse markers and indicates that the Saudi writers tend to make more efforts to make a coherent text. This corresponds with Abbas (2011) who reported that the Arabic researchers use more interactive markers than the native speakers. Also, this finding is supported by Feng (2014) who revealed that the Arabic authors are more faithful to engage the reader in the text and more oriented towards making the text comprehensible to the reader. Moreover, this finding supports Hyland's (2004) suggestion that hedges are highly used in academic writing. Crismore et al. (1993) concluded a similar finding that boosters are attitude markers are not highly frequent in academic writing.

In the whole corpus, transitions were the highly frequent metadiscourse markers in the two types of texts, followed by hedging, evidentials, boosters, and attitude markers, respectively. However, engagement markers were the least frequent metadiscourse markers in the whole corpora of the study. The Saudi authors used all metadiscourse sub-categories more frequently than the British authors except frame markers, evidentials, endophoric markers, and self-mentions.

\section{Conclusion}

This study examines the use of metadiscourse markers by Saudi and British authors in applied linguistics research articles. The study comprised this comparative analysis since the metadiscourse in the writings of Saudi authors is under-researched. In particular, the study tried to identify the kinds of metadiscourse markers used by Saudi and English authors in applied linguistics research articles and to determine the most and least frequent metadiscourse makers used by the two types of authors.

Using a corpus consisting of (20) research articles in the field of applied linguistics, an analysis was made on the abstract and introduction sections of the research articles. (10) research articles were selected for the Saudi authors and (10) research articles for the British authors. The data collection model used in this study is that of Hyland (2005) that comprised two main categories: interactive metadiscourse and interactional metadiscourse. Each main category consisted of five sub-categories. The density of each sub-category per (1000 word) was calculated.

The findings of the study showed the distribution of each sub-category in each type of corpora. Frequency and percentage were the two main statistical tools in this study. The findings of the study concluded that interactive 
metadiscourse markers are highly frequent than the interactional metadiscourse in the whole corpora. In particular, it was shown that the Saudi authors used metadiscourse markers more than the British authors. Transitions were the highly frequent sub-category used in the whole corpora, followed by hedges, evidentials, boosters, and attitude markers, respectively. The number of metadiscourse markers in the texts written by Saudi authors is (870) markers and the number of metadiscourse markers in the texts written by British authors is (668) markers. The Saudi authors used most of the sub-categories in the whole corpora more than the English authors.

This study enhances the understanding of the cultural differences between the Saudi and British authors. Generally, it was found that the Saudi authors has an exaggerated orientation towards the use of metadiscourse markers. This implies that the Saudi authors usually dedicate much attention to the formal dimensions of the text rather to the content. This study has important pedagogical implications the Saudi writers in the field of applied linguistics. In order to be globally recognized as good writers, Saudi authors of applied linguistics have to enhance their awareness of the writing conventions in English. Also, language teachers can adopt the effective teaching method that allow their students good commanders of the academic writing. English language syllabus designers and writing programs designers need to insert the activities and tasks that foster the proper conventions of academic writing.

The current study is only limited to (10) ALRAs written by British authors and (10) ALRAs written by Saudi authors due to the need to focus on metadiscourse markets in each type of articles and to reduce the research scope. This study focused on the abstract and introduction sections in the articles because they are the most important parts with regard to the use of discourse markers in a research article. Furthermore, the limited time allowed for the research to conduct this research was not so long, in addition to the restrictions imposed by Covid-19 resources. However, these limitations shall not strongly impact the results of the study and further studies can focus on a larger corpus in order to be able to generalize the findings effectively. Moreover, further studies can investigate discourse markers in sections other than the abstract and introduction as in this study.

\section{Recommendations}

Based on the research results, the researcher presents the following recommendations:

1) Applied linguistics research articles should be well trained on the foundations of academic writing, especially the use of metadiscourse.

2) Metadiscourse should be effectively taken in consideration when writing an applied linguistic research article in order to yield a material with high levels of intelligibility and communication.

3) Saudi writers of applied linguistics research articles should be well aware of the difference between the discourse communities to know more about the conventions of the different discourse communities.

4) Before making generalizations, a larger corpus is needed and the researchers are encouraged to interview the authors to know about their perspective of using metadiscourse in academic writing.

\section{References}

Abbas, H. J. S. (2011). A contrastive study of metadiscourse in English and Arabic linguistics research articles. ActaLinguistica, 5(1), 28-41.

Al-Bahlal, F. (2015). Hedging devices used in business and scientific texts. Master thesis. King Saud University. Riyadh.

Alharbi, L. M., \& Swales, J. M. (2011). Arabic and English abstracts in bilingual language science journals: Same or different? Languages in Contrast, 11(1), 70-86. https://doi.org/10.1075/lic.11.1.06alh

Ali, N. (2016). Metadiscourse in academic genres: an interdisciplinary study of research articles in Sudan. British Journal of English Linguistics, 4(5), 35-63.

Alotaibi, H. (2015). Metadiscourse in Arabic and English research articles. World Journal of English Language, 5(2), 1-7. https://doi.org/10.5430/wjel.v5n2p1

Connor, U. (1996). Contrastive rhetoric: Cross-cultural aspect of second-language writing. Cambridge University Press. https://doi.org/10.1017/CBO9781139524599

Crismore, A., Markkanen, R., \& Steffensen, M. S. (1993). Metadiscourse in persuasive writing: A study of texts written by American and Finnish university students. Written Communication, 10(1), 39-71. https://doi.org/10.1177/0741088393010001002

Elheky, M., \& Elbahlal, F. (2012). Hedging in social and scientific texts: a comparative study. Master thesis. King Saudi University. Riyadh. 
El-Seidi, M. (2000). Metadiscourse in English and Arabic argumentative writing: A cross linguistic study of texts written by American and Egyptian university students. In Z. M. Ibrahim, S. T. Aydelott, \& N. Kassabgy (Eds.), Diversity in Language: Contrastive Studies in Arabic and English Theoretical and Applied Linguistics (pp. 111-126). Cairo: The American University in Cairo Press.

Gries, L., \& David, M. (2009). This is kind of / sort of interesting: variation in hedging in English. University of California, Santa Barbara.

Hyland, K. (1998). Persuasion and context: The pragmatics of academic discourse. Journal of Pragmatics, 30, 437-455. https://doi.org/10.1016/S0378-2166(98)00009-5

Hyland, K. (2000). Disciplinary discourses: social interactions in academic writing. London: Longman.

Hyland, K. (2002). Options of identity in academic writing. ELT Journal, 56(4), 351-358. https://doi.org/10.1093/elt/56.4.351

Hyland, K. (2005). Metadiscourse: exploring interaction in writing. London; New York: Continuum.

Hyland, K., \& Tse, P. (2004). Metadiscourse in academic writing: A reappraisal. Applied Linguistics, 25(2), 156-177. https://doi.org/10.1093/applin/25.2.156

Kawase, T. (2015). Metadiscourse in the introductions of $\mathrm{PhD}$ theses and research articles. Journal of English for Academic Purposes, 20, 114-124. https://doi.org/10.1016/j.jeap.2015.08.006

Maurenan, A. (1993). Cultural Differences in Academic Rhetoric. Frankfurt: Peter Lang.

Mojica, L. (2005). Filipino authors' ways of showing detachment/commitment in their English academic papers. In D. Dayag \& J. S. Quakenbush (Eds.), Linguistics and Language Education in the Philippines and Beyond: A Festschrift in Honor of Ma. Lourdes S. Bautista (pp. 511-525). Manila: Linguistic Society of the Philippines.

Salek, M. (2014). A diagram of interactive and interactional markers in different parts of English research articles. Journal of Language Sciences \& Linguistics, 2(3), 55-66.

Schiffrin, D. (1980). Meta-talk: Organizational and evaluative brackets in discourse. Sociological Inquiry: Language and social interaction, 50(3-4), 199-236. https://doi.org/10.1111/j.1475-682X.1980.tb00021.x

Sultan, A. (2011). A contrastive study of metadiscourse in English and Arabic linguistics research articles. ActaLinguistica, 5(1), 28-41.

Swales, J. M. (1990). Genre analysis: English in academic and research settings. Cambridge, UK: Cambridge University Press.

Tabrizi, A. (2011). Hedging in scientific and humanistic texts; the comparison between Biology and ELT texts. LAP Lambertb Academic Publishing GmbH \& Co. KG, Saarbrucken, Germany.

VandeKopple, W. J. (1985). Some exploratory discourse on metadiscourse. College Composition and Communication, 36(1), 82-93. https://doi.org/10.2307/357609

Velcro-Grace, C. (1996). Contrastive ESP rhetoric: metatext in Spanish-English economics texts. English for Specific Purposes, 15(4), 279-294. https://doi.org/10.1016/S0889-4906(96)00013-0

Williams, J. (1981). Style: ten lessons in Clarity and GRACE. Boston: Scott Foresman.

Wishnoff, J. R. (2000). Hedging Your Pets: L2 Learners' Acquisition of Pragmatic Devices in Academic Writing and Computer-Mediated Discourse. Second Language Studies, 19(1), 127-157.

\section{Copyrights}

Copyright for this article is retained by the author(s), with first publication rights granted to the journal.

This is an open-access article distributed under the terms and conditions of the Creative Commons Attribution license (http://creativecommons.org/licenses/by/4.0/). 